\title{
Assessment of aflatoxin and heavy metals levels in maize and poultry feeds from Delta State, Nigeria
}

\author{
Idolo Ifie ${ }^{1,2}\left(\right.$ Chinyere G. Igwebuike ${ }^{2} \cdot$ Paul Imasuen $^{2} \cdot$ Winnie Akalamudo $^{2} \cdot$ Obakanurhe Oghenebrorhie $^{2}$. \\ Job O. Akpodiete ${ }^{2}$. Ukpai A. Eze ${ }^{3}$
}

Received: 3 December 2021 / Revised: 4 January 2022 / Accepted: 22 January 2022 / Published online: 22 February 2022

(c) Crown 2022

\begin{abstract}
The aim of this study was to determine the concentration of total aflatoxin and heavy metals (lead cadmium, chromium and copper) in poultry feed and ingredients from two regions (north and central) in Delta State, Nigeria. A total of 120 samples collected (comprising of maize, soybean meal, layers mash and broiler finisher) directly from poultry farms, feed mills and poultry feed dealers were analysed for moisture content, total aflatoxin and heavy metals (lead, cadmium, chromium and copper) concentrations. Moisture content was analysed using standard Association of Official Agricultural Chemists method, while total aflatoxin and heavy metals concentrations were determined by enzyme-linked immunosorbent assay and atomic absorption spectrometry, respectively. Total aflatoxins concentrations ranged from 12.0 to $20 \mu \mathrm{g} / \mathrm{kg}$ and 21 to $31 \mu \mathrm{g} / \mathrm{kg}$ in samples from north and central region, respectively. Apart from maize, aflatoxin content in other samples from the north was marginally lower $(18-20 \mu \mathrm{g} / \mathrm{kg})$ than permitted levels. On the other hand, aflatoxin levels in samples from the central were all above tolerable limits. Copper content in samples was less than permissible limit, while 44.4, 29.1 and $21 \%$ of samples had concentrations of lead, cadmium and chromium, respectively, above permissible limit. The presence of aflatoxin and lead in poultry feeds above permissible limits of $20 \mu \mathrm{g} / \mathrm{kg}$ and $5 \mathrm{mg} / \mathrm{kg}$, respectively, may pose a risk for animal productivity and human health.
\end{abstract}

Keywords Aflatoxins $\cdot$ Finished poultry feeds $\cdot$ Heavy metals $\cdot$ Permissible limits $\cdot$ Poultry feed ingredients

\section{Introduction}

In recent years, the Nigerian poultry industry has been rapidly expanding and has become one of the most commercialized sub-sectors of Nigerian agriculture (United States Department of Agriculture USDA 2010). However, poultry feeds which comprises of maize, peanut meal, soya bean meal and mixtures of maize, groundnut cake and other crops

Editorial responsibility: Maryam Shabani.

Idolo Ifie

i.ifie@leeds.ac.uk

1 Present Address: School of Food Science and Nitrition, University of Leeds, Leeds LS2 9JT, UK

2 Food Science and Technology Unit, Department of Animal Science, Delta State University, Abraka, PMB 1, Delta State, Nigeria

3 School of Life Sciences, Faculty of Health and Life Sciences, Coventry University, CV1 5FB, Coventry, UK have been associated with mycotoxin contamination during crop production and storage (Getachew et al. 2018), with limited attention given to this by local poultry farmers and regulatory bodies. Food and Agriculture Organization report states that about up to a quarter of the world's growing crops are affected by mycotoxins each year (Imade et al. 2021). In a recent study on mycotoxin contamination in maize and finished feed samples from 8 African countries, 33.3\% of maize samples and $54.4 \%$ of finished feed samples were above the European regulatory limit of $20 \mathrm{ng} / \mathrm{g}$ aflatoxins (Gruber-Dorninger et al. 2018). The maximum permitted level for aflatoxin $\mathrm{B}_{1}\left(\mathrm{AFB}_{1}\right)$ is $20 \mu \mathrm{g} / \mathrm{kg}$ and recommended values for deoxynivalenol (DON), zearalenone (ZEN), T-2, ochratoxin A (OTA) and fumonisins (FB1 + FB2) are 5, $0.25,0.25,0.1$ and $20 \mathrm{mg} / \mathrm{kg}$, respectively, in poultry feed (Commission 2006). For poultry feed ingredients, (maize soybean meal, etc.) permitted levels of mycotoxins range from 0.02 to $0.1 \mathrm{mg} / \mathrm{kg}$ (Magnoli et al. 2019).

The losses resulting from mycotoxin contamination are numerous, ranging from loss of value of commodities, 
which translates to trade and economic losses, decline in animal productivity and ultimately human health cost which in fatal cases might result in death (Bhat Ramesh and Vasanthi 2003; Rodrigues et al. 2011; Shephard 2008). Aflatoxins (AF) formed by strains of Aspergillus flavus, A. flavus subsp. parasiticus and Asperigillus nomius have received greater attention than any other mycotoxins, and among the types of $A F s$ reported, aflatoxin $\mathrm{B}_{1}\left(\mathrm{AFB}_{1}\right)$, aflatoxin $\mathrm{G}_{1}\left(\mathrm{AFG}_{1}\right)$, aflatoxin $\mathrm{B}_{2}\left(\mathrm{AFB}_{2}\right)$ and aflatoxin $\mathrm{G}_{2}\left(\mathrm{AFG}_{2}\right)$ are the most toxic to human health (Nasir et al. 2021). The effect of domestic animals ingesting feed infected with even sub-lethal doses of AF includes reduced output and reproduction, increased vulnerability to diseases and decreased quality of foods produced (Joint et al. 2017).

According to International Agency of Research on Cancer Agency for Research on Cancer (IARC), AF, especially AFB1, is classified as group 1 human carcinogen (Nasir et al. 2021; WHO 1993). AF residues are predominant in eggs, milk, meat flesh and organs, and their consumption by humans is a major route of mycotoxin intake causing a wide range of harmful effects (Adegbeye et al. 2020; Li et al. 2021). There are a number of environmental conditions that favour the growth and production of mycotoxins, namely humidity, temperature, moisture and handling conditions during harvest and storage (Mutegi et al. 2013). In Nigeria, humid environmental circumstances (average RH: $84 \%$ and $33{ }^{\circ} \mathrm{C}$ ) coupled with improper and inefficient storage practices present ideal conditions for fungal growth and then, mycotoxin production. The risk of mycotoxin contamination in poultry feeds in Nigeria is further heightened by lack of strict regulations regarding feeds and feed materials in the poultry sector (Rodrigues et al. 2011). Therefore, extensive studies on the prevalence of AF contamination in poultry feeds from different geographical regions in Nigeria are needed for the purpose of legislation and adopting effective strategies aimed at controlling its occurrence (Ezekiel et al. 2012).

Heavy metals are a group of contaminants in feed materials and animal feeds. These heavy metals, including cadmium $(\mathrm{Cd})$, lead $(\mathrm{Pb})$, copper $(\mathrm{Cu})$ and chromium $(\mathrm{Cr})$, have specificity density in excess of $5 \mathrm{~g} / \mathrm{cms}$ and are toxic or poisonous even at low concentrations (Duruibe et al. 2007; Järup 2003). The route through which these toxic substances contaminate plant materials includes the use of polluted water for irrigation, fertilisers, toxic pesticides and industrial activities such as mineral and oil exploration and postharvest contamination (Alkhalaf et al. 2010). Farm animals ingest these contaminated plant materials and subsequently pass these toxic substances up the food chain to humans via animal products (Hinton 2000). The adverse effects associated with heavy metal intake include damage to the lungs, kidneys, tissues and skeletal system, osteoporosis and, in some instances, cause cancer of the lungs and blood (Akhtar et al. 2017; Blair and Lamb 2017; Ismail et al. 2014; Rebelo and Caldas 2016).

Although there are several studies on the occurrence of heavy metals in animal products (Cang et al. 2004; Javed et al. 2009; Tajkarimi et al. 2008; Vidovic et al. 2005), data on the prevalence of heavy metals contamination in poultry feeds and ingredients in Nigeria are scanty. The ubiquitous nature of food-borne mycotoxins (e.g. aflatoxins) and environmental contaminants (e.g. heavy metals) makes possible their entry into the animal portion and food chain either during the harvest, storage or processing period. In addition, sewage sludge and sewage water are commonly applied in most farms and pastures by subsistence farmers which multiplies the toxic metals in the soil environment and forage pastures in these farms. In addition, the oil exploration and mineral mining in the Niger Delta region of Nigeria result in the contamination of farm settlements by heavy metals. These are either taken up by plants or contaminate the farm produce and thereafter transferred into the food chain. Since such co-contamination is inevitable and could increase the possibility of inducing toxic effects in humans and animals, it is important to evaluate such co-contamination to understand the risk posed by such mixtures of contaminants spanning different chemical groups. Therefore, the aim of this study was to assess the co-contamination of total AF and heavy $(\mathrm{Cd}, \mathrm{Pb}, \mathrm{Cr}$ and $\mathrm{Cu})$ of poultry feeds and ingredients from two regions (North \& Central) between the months of October 2019-January 2020 in Delta State, Nigeria.

\section{Materials and methods}

\section{Sampling method}

A total of 120 poultry feeds and poultry feed ingredients from two regions (North and Central) of Delta State, Nigeria, comprising of maize $(n=30)$, broiler finisher $(n=30)$, layers mash $(n=30)$ and soybean meal $(n=30)$ were randomly collected from different poultry farmers $(n=5)$, feed mills $(n=5)$ and feed dealers $(n=5)$ for each sample group in each region bringing the total number of samples collected from each region to be 60 each. In addition, crude oil exploration activities are more prevalent in the central than northern region (Fig. 1). The feed samples were properly packaged in separate clean zip-lock polythene bags, labelled and transported to the laboratory and stored frozen $\left(-20{ }^{\circ} \mathrm{C}\right)$ to prevent further production of the metabolite by fungi and bacteria prior to $\mathrm{AF}$ and heavy metal analysis. 


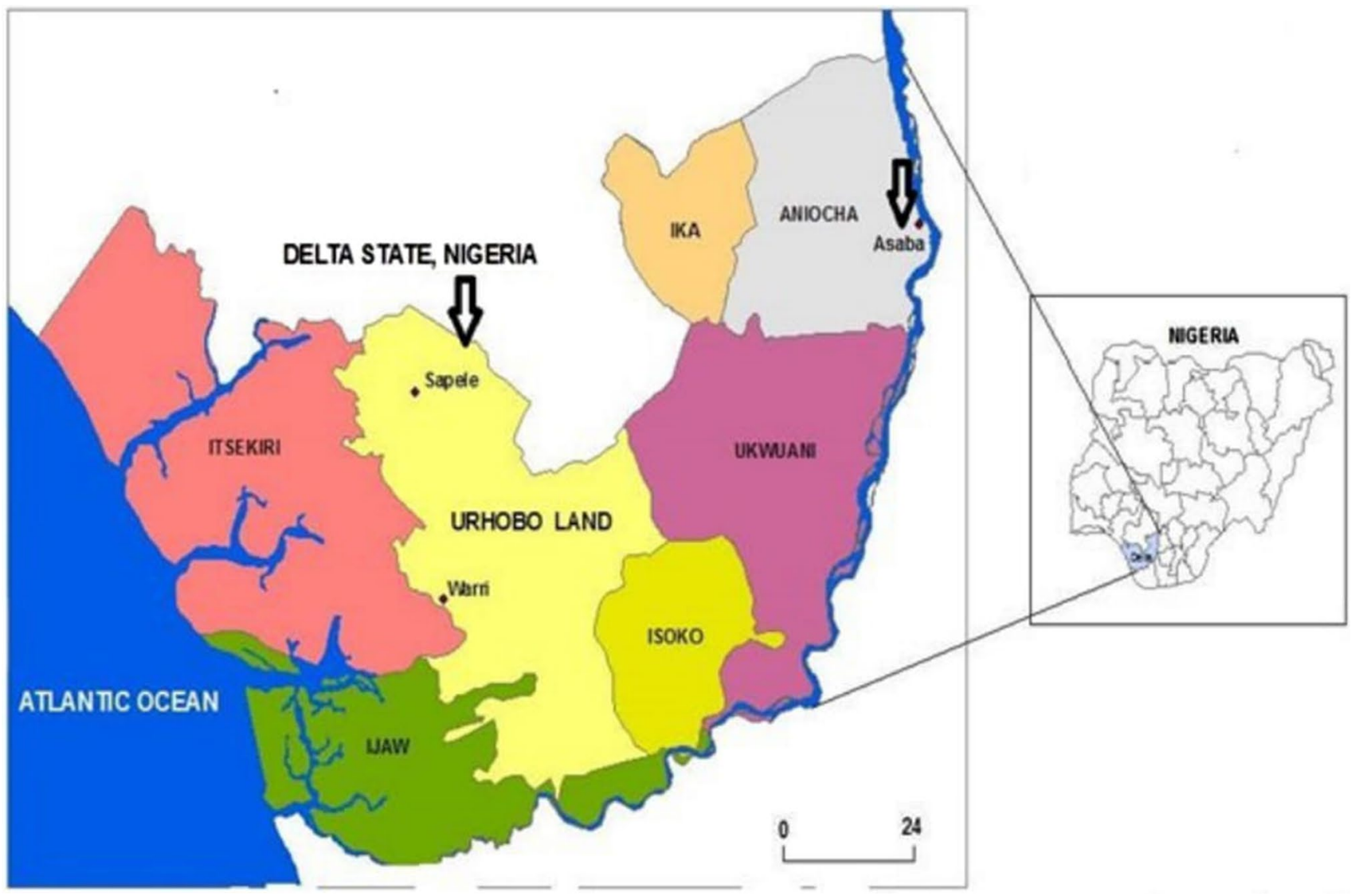

Fig. 1 Locations of sampled sites in Central and Northern regions of Delta State, Nigeria Asaba is located on Latitude: 6 $6^{\circ} 11^{\prime} 53^{\prime \prime} \mathrm{N}$, and Longitude: $6^{\circ} 43^{\prime} 54^{\prime \prime}$ E. The elevation above sea level is $46 \mathrm{~m}(150$ $\mathrm{ft}$.). The least amount of rainfall occurs in December $(11 \mathrm{~mm})$, while September has the highest rainfall $(313 \mathrm{~mm})$. The average $\mathrm{RH}$ of

\section{Determination of moisture content}

The moisture content of samples was determined using the standard oven method (Association of Official Agricultural Chemists AOAC 1990). The frozen samples were allowed to thaw at room temperature. Thereafter, they were weighed, dried in triplicate at $105{ }^{\circ} \mathrm{C}$ to a constant weight, and the average moisture content was determined on a percentage dry basis.

\section{AF extraction and analysis}

The extraction and analysis of AF in samples were evaluated after slight modifications according to the method of Kana et al. (2013). Twenty-five (25 g) of all samples collected were measured in triplicates and ground using a roller mill and poured into a conical flask. For extraction of $\mathrm{AF}, 25 \mathrm{~mL}$ of $70 \%$ methanol solution was poured into each of the flask containing the milled sample and thoroughly mixed using a rotatory shaker operated at $225 \mathrm{rpm}$
Asaba is around $78 \%$. Sapele is located on Latitude $5^{\circ} 53^{\prime} 38^{\prime \prime} \mathrm{N}$ and Longitude $5^{\circ} 40^{\prime} 35^{\prime \prime} \mathrm{E}$. The elevation above sea level is $11 \mathrm{~m}(36$ ft.).Rainfall is at its peak between June and July with an average rainfall of $431 \mathrm{~mm}$, while the lowest rainfall of $7.62 \mathrm{~mm}$ occurs in January. The average $\mathrm{RH}$ of Sapele is around $85 \%$

for $4 \mathrm{~min}$ at $25^{\circ} \mathrm{C}$. The mixture was passed through a filter paper (Whatman No. 1) and $2 \mathrm{~mL}$ of the filtrate pipetted into a $10 \mathrm{~mL}$ flask and filled to the mark with distilled water. For sample clean up, the diluted extract was passed through an Aflatest ${ }^{\circledR}-\mathrm{P}$ affinity column (VICAM) at a rate of 1-2 drops/second and to remove impurities, and the column was rinsed with distilled water. HPLC grade methanol was then passed through the affinity column at a rate of 1-2 drops/second for elution of bound AF and the eluate collected in a cuvette. For AF analysis, $1 \mathrm{~mL}$ of Aflatest ${ }^{\circledR}$ developer solution (VICAM) was added to the eluate and mixed thoroughly. The cuvette was then placed in a microtiter plate reader (BioTek) earlier calibrated according to the manufacturer's protocol, and after $60 \mathrm{~s}$, total AF concentration $(\mathrm{B} 1+\mathrm{B} 2+\mathrm{G} 1+\mathrm{G} 2)(\mu \mathrm{g} / \mathrm{kg})$ in the samples was read and recorded. The analysis of AF from each sample was carried out in triplicates.

The linearity of the method was tested by running AF standard in the range of $0.0-40 \mu \mathrm{g} / \mathrm{kg}(0,2,10,20$ and $40 \mu \mathrm{g} / \mathrm{kg}$ ), and a correlation coefficient $\left(R^{2}\right)$ of 0.9913 was 
obtained. The method was reproducible, and the range of $\mathrm{CV}$ for inter-day precision was $0.35-4.01$. The limit of detection (LOD) and limit of quantification (LOQ) of the method were 3 and $4 \mu \mathrm{g} / \mathrm{kg}$, respectively. The recovery of method of aflatoxin analysis was evaluated by spiking uncontaminated maize samples with standard aflatoxin concentrations of 20 and $30 \mu \mathrm{g} / \mathrm{kg}$ and the recovery of analyte was $91.6 \& 107.2 \%$ respectively.

\section{Determination of heavy metals in feed samples}

Feed samples were analysed for lead, cadmium and copper and chromium contents using atomic absorption spectrophotometry (AAS) as described by Ifie et al. (2021). For the destruction of organic matter, the dry ashing method was employed. The samples were placed in partially covered and dried in a convention oven set at $100-105^{\circ} \mathrm{C}$ overnight $(16 \mathrm{~h})$. To aid the ashing process, magnesium nitrate was added to the dried sample at approximately $1: 1$ ratio. Samples were burnt on a hot plate $(2 \mathrm{~h})$, and ashing was performed in a muffle furnace at $470{ }^{\circ} \mathrm{C}$ for $16 \mathrm{~h}$. Ash was extracted with $20 \%(\mathrm{v} / \mathrm{v})$ redistilled nitric acid and filled to a definite volume with $1 \%$ nitric acid (v/v) for analysis. An atomic absorption spectrophotometer (model 2380, PerkinElmer, Waltham, MA) with flame atomization (air-acetylene) 60-20, equipped with a burner and a deuterium lamp for background correction, was employed for determination of concentrations of toxic metals. The extraction of ash from each sample was carried out in triplicates.

The method for analysis of heavy in samples was evaluated for linearity precision and accuracy. For each heavy, five calibrations of pure commercial standards of lead, cadmium copper and chromium ranging $0.1-8.0 \mathrm{mg} / \mathrm{kg}$ were prepared to evaluate the linearity of the method. The value of the coefficient of correlation $(r$ ) calculated for lead, cadmium, copper and chromium was $0.9963,0.9999,1.000$ and 0.9983 , respectively. Regarding accuracy, the test of accuracy was done by the standard addition method. Three concentration of standard solution $(0.5,1.0$ and $2.0 \mathrm{mg} / \mathrm{kg})$ were added to the sample and the \% recovery calculated ranged from 96.8 to $99.3 \%$. The LOD and LLOQ determined were $1 \mu \mathrm{g} / \mathrm{kg}$ and $3 \mu \mathrm{g} / \mathrm{kg}$, respectively.

\section{Data analysis}

Data analyses were carried out using IBM SPSS software (Version 20.0), and Duncan's multiple range was used to separate differences in means among samples. Statistical analysis was performed comparing the results of all samples together, and values for statistically significant difference were set at $p<0.05$.

\section{Result and discussion}

\section{Moisture content between samples}

One of the major factors influencing AF accumulation in poultry feeds and maize after harvesting is the moisture content. It has been demonstrated that temperatures of $25-30{ }^{\circ} \mathrm{C}$, moisture contents of above $16 \%$ and water activity $\left(\mathrm{a}_{\mathrm{w}}\right)$ of above 0.70 encourage fungal growth and mycotoxins production (Mannaa and Kim 2017; Thanushree et al. 2019). The mean scores of moisture content (Table 1) fell within the range of $10.38-12.41 \%$ and $11.38-14.75 \%$ for samples collected in the northern and central regions, respectively. The results also showed that soybean meal samples $(14.75 \%)$ from the central region was highest in moisture content. Mogan and Lacy (1988) reported that moisture content $\leq 15 \%$ in maize is safe for storage, although there have been incidences of mould growth within the temperature range of $10-40{ }^{\circ} \mathrm{C}$ and equilibrium relative humidity above 70\% (D'Mello 1997; Lanyasunya et al. 2005). Kana et al. (2013) analyzed the moisture content of maize, peanut meal and poultry feed mixtures from three agro-ecological zones in Cameroon and reported a range of $10-14 \%$ moisture content. In a similar study, the moisture content of poultry feed across five agro-ecological zones in Nigeria ranged from 9.8 to $12.4 \%$ (Ezekiel et al. 2014). Comparing the data on moisture content from both regions showed that feed samples from the Delta central presented higher values and this may be due to higher relative humidity found in the central region. The Pearson correlation coefficient of linear regression between the relative humidity $(\mathrm{RH})$ and $\mathrm{AF}$ levels

Table 1 Average moisture content of maize, broiler marsh, layers mash and soybean meal collected from two regions in Delta State, Nigeria

\begin{tabular}{lllll}
\hline Commodity & $\begin{array}{l}\text { Zone sam- } \\
\text { ples }\end{array}$ & $\begin{array}{l}\text { Number } \\
\text { of sam- } \\
\text { ples }\end{array}$ & $\begin{array}{l}\text { Moisture } \\
\text { content (\%) } \\
\text { Mean } \pm \text { STD }\end{array}$ & Range (\%) \\
\hline Maize & North & 15 & $12.41 \pm 1.88^{\mathrm{b}}$ & $9.8-14.6$ \\
& Central & 15 & $11.38 \pm 1.11^{\mathrm{bc}}$ & $9.33-13.81$ \\
Broiler & North & 15 & $12.23 \pm 1.05^{\mathrm{a}}$ & $9.8-15.4$ \\
finisher & Central & 15 & $13.10 \pm 1.91^{\mathrm{ab}}$ & $9.87-17.89$ \\
Layers mash & North & 15 & $11.73 \pm 4.08^{\mathrm{bc}}$ & $9.2-15.20$ \\
& Central & 15 & $12.79 \pm 3.11^{\mathrm{b}}$ & $9.13-19.80$ \\
Soy bean & North & 15 & $10.38 \pm 2.01^{\mathrm{c}}$ & $8.6-12.0$ \\
meal & Central & 15 & $14.75 \pm 2.61^{\mathrm{a}}$ & $9.6-18.55$ \\
\hline
\end{tabular}

The results represent the average determination of moisture content $(n=3)$ of feed samples collected from two regions in Delta State, Nigeria. Statistical analysis was performed comparing the results of all samples together, and values with different letter superscripts on the same column are statistically significantly different $(p<0.05)$ 
showed a moderate correlation $\left(R^{2}=0.40\right)$ with higher $\mathrm{AF}$ occurrence of samples in the central region with higher $\mathrm{RH}$.

\section{AF occurrence of samples}

According to the European Union (EU) and Food and Agriculture Organization (FAO) legislation, the maximum tolerable levels for total AF in poultry feeds are $20 \mu \mathrm{g} / \mathrm{kg}$ (FAO 2004; Nasaruddin et al. 2021). In Nigeria, the European Commission and Codex Alimentarius Standards mycotoxin regulations were adopted and are used primarily for export commodities. The maximum acceptable limit for aflatoxins is $10 \mu \mathrm{g} / \mathrm{kg}-20 \mu \mathrm{g} / \mathrm{kg}$, especially for all cereal and all products derived from cereals (Imade et al. 2021).

The result of total AF contamination between samples from both regions is presented in Table 2. AF was detected in $\sim 80 \%$ of the samples, and this agrees with other published data on the occurrence of AF contamination in poultry feeds and feed ingredients in Nigeria (Akinmusire et al. 2019; Daodu and Adebowale 2016). Samples collected in the northern region showed no statistical significant difference $(p>0.05)$ in AF contamination between layers mash, broiler finisher and soybean meal. However, maize which recorded the lowest AF contamination $(12 \mu \mathrm{g} / \mathrm{kg})$ was significantly different $(P=0.027)$ from soybean. On the contrary, maize from the central region recorded the highest level of AF contamination $(31 \mu \mathrm{g} / \mathrm{kg})$ in samples from both regions. The level of AF contamination of maize in this study coincides with similar research findings on maize AF contamination from three sites in Uganda and South Brazil which ranged from 12.8 to $30 \mu \mathrm{g} / \mathrm{kg}$ and 16.7 to $49.9 \mu \mathrm{g} / \mathrm{kg}$, respectively (Kaaya and Kyamuhangire 2006; Oliveira et al. 2017). However, in another study, the range of AF contamination in maize from different locations in Nigeria $(5-1200 \mu \mathrm{g} / \mathrm{kg})$, Ghana $(4-140 \mu \mathrm{g} /$ $\mathrm{kg}$ ) and Kenya $(0.5-89 \mu \mathrm{g} / \mathrm{kg}$ ) was much higher (Kemboi et al. 2020; Perrone et al. 2014). Similarly, $\mathrm{AFB}_{1}$ mean concentration in maize samples from five districts in two agro-ecological zones in Senegal ranged from 5 to $188 \mu \mathrm{g} /$ $\mathrm{kg}$ (Diedhiou et al. 2011). Although there was no significant difference $(p<0.05)$ in AF contamination between layers mash and broiler finisher from the northern region, the levels were higher in layers mash in the central region. This occurrence is contrary to a previous study carried out in Cameroon (Kana et al. 2013), where the mean AF contamination in broiler feed $(6.66 \mu \mathrm{g} / \mathrm{kg})$ was higher than layers mash $(11.1 \mu \mathrm{g} / \mathrm{kg})$.

In a published study (Nemati et al. 2010) from northwestern region of Iran, the mean concentrations of AF contamination in broiler feed $(11.6 \mu \mathrm{g} / \mathrm{kg})$ and soybean meal $(6.01 \mu \mathrm{g} / \mathrm{kg})$ were lower than the results (18 and $21 \mu \mathrm{g} / \mathrm{kg}$ broiler finisher and 20 and $30 \mu \mathrm{g} / \mathrm{kg}$ soybean meal) from this study. AF contaminations in this study were also higher than results from Guyana, where mean concentrations of $\mathrm{AF}$ in poultry feeds and ingredients ranged from 3.81 to $27.38 \mu \mathrm{g} /$ $\mathrm{kg}$ (Morrison et al. 2017). Similarly, $\mathrm{AFB}_{1}$ contamination in corn, wheat and commercial poultry feeds purchased from popular markets in Morocco was also lower than our reported values with concentrations ranging from 0.03 to $11.2 \mu \mathrm{g} / \mathrm{kg}$ (Zinedine et al. 2007). Nevertheless, in India, higher incidences of AFs were recorded and were in the range of $10-3500 \mu \mathrm{g} / \mathrm{kg}$ for groundnut cake and sorghum samples; $10-1500 \mu \mathrm{g} / \mathrm{kg}$ in mixed feed samples; $10-300 \mu \mathrm{g} /$ $\mathrm{kg}$ in maize and $10-100 \mu \mathrm{g} / \mathrm{kg}$ in rice bran (Thirumala-Devi et al. 2002). Higher levels (24. $-185.25 \mu \mathrm{g} / \mathrm{kg}$ ) of AF were also observed in different types of chicken from large-scale and small-scale processors in Uganda (Nakavuma et al. 2020). Aboagye-Nuamah et al. (2021) also reported higher AF values $(11.83-88.37 \mu \mathrm{g} / \mathrm{kg})$ in poultry feed samples from Ghana compared to results obtained in this study. The variations in AF contamination seen can be attributed to differences in geographical location, weather, and farming and
Table 2 Level of total aflatoxin contamination in maize, broiler marsh, layers mash and soybean meal collected from two regions in Delta State, Nigeria

\begin{tabular}{llllll}
\hline Commodity & Zone & $\begin{array}{l}\text { Number } \\
\text { of samples }\end{array}$ & $\begin{array}{l}\text { Aflatoxin concen- } \\
\text { tration (ug/kg) } \\
\text { Mean } \pm \text { STD }\end{array}$ & $\begin{array}{l}\text { No/Percentage of sam- } \\
\text { ples above-permitted } \\
\text { levels }\end{array}$ & Range (ug/kg) \\
\hline Maize & North & 15 & $12.0 \pm 8.48^{\mathrm{c}}$ & $3(20.0 \%)$ & $4.0-21.0$ \\
& Central & 15 & $31.0 \pm 62.22^{\mathrm{a}}$ & $8(53.3 \%)$ & $9.0-98.0$ \\
Broiler finisher & North & 15 & $18.0 \pm 6.54^{\mathrm{bc}}$ & $3(20 \%)$ & $8.0-29.0$ \\
& Central & 15 & $21.0 \pm 17.54^{\mathrm{b}}$ & $10(66.6 \%)$ & $11.0-55.0$ \\
Layers mash & North & 15 & $19.0 \pm 20.74^{\mathrm{bc}}$ & $4(26.67 \%)$ & $8.0-68.0$ \\
& Central & 15 & $30.0 \pm 18.15^{\mathrm{a}}$ & $12(80.0 \%)$ & $14.0-58.0$ \\
Soybean meal & North & 15 & $20.0 \pm 13.16^{\mathrm{b}}$ & $8(53.3 \%)$ & $4.0-45.0$ \\
& Central & 15 & $30.0 \pm 19.80^{\mathrm{a}}$ & $13(86.67 \%)$ & $11.0-56.0$ \\
\hline
\end{tabular}

The results represent the average determination of aflatoxin concentrations $(n=3)$ of feed samples collected from two regions in Delta State, Nigeria. Statistical analysis was performed comparing the results of all samples together, and values with different letter superscripts on the same column are statistically significantly different $(\mathrm{p}<0.05)$ 
storage practices. Aflatoxin in farm produces can be kept within permissible by adopting best practices such as use of drought-tolerant varieties; timely harvesting before physiological maturity; sorting to remove damaged ears and those having poor husk covering; drying to moisture content of $13 \%$; storage in suitable conditions to keep the crop clean and under condition with minimally proper aeration, or ideally under hermetic conditions (Xu et al. 2021).

\section{Level of heavy metals occurrence in samples}

The mean concentrations of heavy metals contaminations in samples from both regions are presented in Table 3. Currently, Nigeria does not have established maximum admissible levels of chromium, copper, lead and cadmium on feed and foods. However, the EU Directive on toxic substances in animal feed prescribed maximum levels of lead, cadmium and copper as 5, 0.5 and $40 \mathrm{mg} \mathrm{kg}^{-1}$, respectively (EU 2013; NRC 2005). $\mathrm{Pb}$ is reported to be a commonly encountered contaminant in the environment (Karak and Bhagat 2010). In this study, the concentration of $\mathrm{Pb}$ in samples from central region testing positive (67\%) ranged from 2.10 to $13.10 \mathrm{mg} /$ $\mathrm{kg}$, while levels of $\mathrm{Pb}$ positive samples (50\%) from the northern region ranged from 2.10 to $11.0 \mathrm{mg} / \mathrm{kg}$. Furthermore, positive samples having concentrations above established limits were $75 \%$ and $67 \%$ for central and northern regions, respectively. In comparison with other published data, Elliot et al. (2017) in an extensive study involving 29 countries from 2009 to 2016 (Asia-Pacific, North and Latin America) analyzed $\mathrm{Pb}$ contamination in poultry feeds and reported concentrations as high as $722 \mathrm{mg} / \mathrm{kg}$, far exceeding amounts observed in this research. On the contrary, Eskandari and Pakfetrat (2014) showed that $\mathrm{Pb}$ content in all animal feed samples analyzed from Southwestern Iran was lower than $5 \mathrm{mg} / \mathrm{kg}$. Wolf and Cappai (2020) also reported lower $\mathrm{Pb}$ concentrations $(0.137-0.369 \mathrm{mg} / \mathrm{kg})$ in poultry feed from northern Germany. Although $\mathrm{Pb}$ is a contaminant that generally occurs naturally in traces on the Earth's surface, its

Table 3 Heavy metal contamination in maize, broiler marsh, layers mash and soybean meal collected from two regions in Delta State, Nigeria

\begin{tabular}{|c|c|c|c|c|c|c|c|c|}
\hline \multirow[t]{3}{*}{ Samples } & \multicolumn{8}{|c|}{ Concentration of heavy metals $(\mathrm{mg} / \mathrm{kg})$} \\
\hline & \multicolumn{2}{|l|}{ Lead } & \multicolumn{2}{|c|}{ Cadmium } & \multicolumn{2}{|c|}{ Chromium } & \multicolumn{2}{|l|}{ Copper } \\
\hline & North & Central & North & Central & North & Central & North & Central \\
\hline \multicolumn{9}{|l|}{ Maize } \\
\hline Mean & $2.87^{\mathrm{c}}$ & $1.7^{\mathrm{c}}$ & nd & $0.2^{\mathrm{bc}}$ & $0.24^{\mathrm{c}}$ & $1.40^{\mathrm{a}}$ & $1.33^{\mathrm{d}}$ & $4.57^{\mathrm{cd}}$ \\
\hline SD & 4.3 & 1.3 & - & 0.27 & 0.35 & 0.26 & 1.5 & 1.21 \\
\hline Min & - & - & - & - & 0.001 & 1.0 & - & 3.0 \\
\hline $\operatorname{Max}$ & 8.9 & 2.9 & - & 0.7 & 0.73 & 1.8 & 3.5 & 6.4 \\
\hline$\%$ of positive samples above permissible level & $100 \%$ & - & - & $66.6 \%$ & $33.3 \%$ & $100 \%$ & - & - \\
\hline \multicolumn{9}{|l|}{ Soybean } \\
\hline Mean & $0.7^{\mathrm{c}}$ & $0.001^{\mathrm{c}}$ & $0.14^{\mathrm{c}}$ & $0.08^{\mathrm{c}}$ & $0.25^{\mathrm{c}}$ & $0.33^{\mathrm{c}}$ & $7.40^{\mathrm{bc}}$ & $5.01^{\mathrm{cd}}$ \\
\hline SD & 1.15 & 0.0 & 0.21 & 0.07 & 0.37 & 0.50 & 1.07 & 1.44 \\
\hline Min & - & - & - & - & 0.001 & 0.001 & 5.9 & 3.0 \\
\hline Max & 2.4 & 0.001 & 0.5 & 0.2 & 0.8 & 0.62 & 8.8 & 6.2 \\
\hline$\%$ of positive samples above permissible level & - & - & $33.3 \%$ & - & $33.3 \%$ & $33.3 \%$ & - & - \\
\hline \multicolumn{9}{|l|}{ Broiler finisher } \\
\hline Mean & $6.6^{\mathrm{ab}}$ & $6.8^{\mathrm{ab}}$ & $0.24^{\mathrm{bc}}$ & $0.59^{\mathrm{a}}$ & $0.001^{\mathrm{c}}$ & $0.87^{\mathrm{b}}$ & $10.58^{\mathrm{b}}$ & $7.93^{\mathrm{bc}}$ \\
\hline $\mathrm{SD}$ & 5.02 & 1.26 & 0.27 & 0.15 & - & 0.62 & 4.93 & 1.61 \\
\hline Min & - & 5.1 & 0.0 & 0.4 & 0.001 & 0.18 & 5.4 & 6.0 \\
\hline $\operatorname{Max}$ & 11.0 & 8.4 & 0.7 & 0.8 & 0.001 & 1.6 & 17.0 & 10.0 \\
\hline$\%$ of positive samples above permissible level & $100 \%$ & $100 \%$ & $50 \%$ & $66.6 \%$ & - & $66.6 \%$ & - & - \\
\hline \multicolumn{9}{|l|}{ Layers mash } \\
\hline Mean & $3.3 b^{c}$ & $8.2^{\mathrm{a}}$ & $0.11^{\mathrm{c}}$ & $0.51^{\mathrm{ab}}$ & $0.001^{\mathrm{c}}$ & $0.20^{\mathrm{c}}$ & $4.62^{\mathrm{cd}}$ & $15.70^{\mathrm{a}}$ \\
\hline SD & 2.49 & 3.62 & 0.17 & 0.45 & - & 0.3 & 1.30 & 7.67 \\
\hline Min & - & 5.20 & - & 0.10 & 0.001 & 0.001 & 3.4 & 6.50 \\
\hline Max & 5.30 & 13.10 & 0.40 & 1.20 & 0.001 & 0.62 & 6.6 & 24.70 \\
\hline$\%$ of positive samples above permissible level & $100 \%$ & $50 \%$ & - & - & - & $33.3 \%$ & - & - \\
\hline
\end{tabular}

The results represent the average determination of heavy metal concentrations $(n=3)$ of feed samples collected from two regions in Delta State, Nigeria. Statistical analysis was performed comparing all the results of individual heavy metals together, and values with different letter superscripts on the same column are statistically significantly different $(p<0.05)$ 
contamination in plant material increases from industrial and urban pollution (Alloway 2013). In humans, the tolerable limit for $\mathrm{Pb}$ is $250 \mu \mathrm{g} / \mathrm{day}$ for adults and $90 \mu \mathrm{g} / \mathrm{day}$ for children (Sharma et al. 2005). Pb toxicity is more common and life threatening in children and aged adults, with neurological and cognitive defects, cardiovascular, renal, gastrointestinal, hepatic and immunological disorders (Dai et al. 2016). In 2010, there was a report of outbreaks of $\mathrm{Pb}$ poisoning due to artisanal gold mining in villages in Zamfara State, Nigeria, which led to the death of 118 children less 5 years old (Dooyema et al. 2012). Similarly, co-exposure to $\mathrm{Pb}$ and $\mathrm{Hg}$ among artisanal gold miners has been reported in Bukkuyum Local Government Area of Zamfara State, Nigeria (Rabiu et al. 2019). In a more recent study, Pona et al. (2021) reported that $\mathrm{Pb}$ exposure in Nigeria caused over 2,500 deaths and about 600 thousand disability-adjusted life years (DALYs) lost yearly between 2007 and 2017, with a steady increase in cardiovascular disease and ischaemic heart diseases. $\mathrm{Pb}$ toxicity in poultry has also been observed in North-Western Nigeria with concentrations in the tissues ranging between $7.5 \mathrm{mg} / \mathrm{kg}$ and $120.5 \mathrm{mg} / \mathrm{kg}$ wet weight (Oladipo et al. 2020).

Cadmium is a heavy metal that has no function in the human body and poses health risk for both human $(0.1 \mathrm{mg} /$ $\mathrm{kg})$ and animal $(0.5 \mathrm{mg} / \mathrm{kg})$ at levels that are not phytotoxic to plants (Peralta-Videa et al. 2009; Yurdakök 2015).

The data from this research showed that samples testing positive for Cd were 75\% (0.09-1.12 mg/kg) and 34\% $(0.1-0.7 \mathrm{mg} / \mathrm{kg})$ in the central and north, respectively. Furthermore, $27.7 \%$ and $5.5 \%$ of samples testing positive in central and northern region, respectively, were above the EU permissible limit. In two separate studies, Cd levels in poultry feed and ingredients from Pakistan and Bulgaria ranged from 0.11 to $1.41 \mathrm{mg} / \mathrm{kg}$ and 0 to $1.8 \mathrm{mg} / \mathrm{kg}$, respectively (Alexieva et al. 2007; Imran et al. 2014). Although the intake of $\mathrm{Cd}$ by plants is generally below $1 \mathrm{mg} \mathrm{kg}^{-1}$ of dry matter, cadmium contents higher than $10 \mathrm{mg} \mathrm{kg}^{-1}$ have been reported in crops grown near industrial areas and in farm produce after application of cadmium-enriched fertilizers (Fink-Gremmels 2012; Wolf and Cappai 2020). Cd toxicity has been linked with nephrotoxicity, osteoporosis, neurotoxicity, carcinogenicity and negative reproductive effects (EFSA (European Food Safety Authority), 2004; EFSA (European Food Safety Authority), 2009).

For several decades, Cr was considered an essential nutrient; however, recently, this position has changed as the beneficial effects from $\mathrm{Cr}$ occur at high pharmacologically relevant doses, in excess of nutritionally relevant doses. As a result, the EFSA has recently determined that no evidence exists on chromium being a basic heavy metal for humans or animals (Vincent 2017). The data on Cr content in feed samples in this study were found to be at very low levels, insufficient to present health hazards. The highest concentration recorded was observed in maize samples from central region $(1.80 \mathrm{mg} / \mathrm{kg})$. The chromium content in 12 different commercial poultry feeds (starter feed, grower feed, and finisher feed) from Bangladesh was analyzed, and the levels in 10 of the 12 feed samples were less than $0.03 \mathrm{mg} / \mathrm{kg}$ (Ahmed et al. 2017). In another study, $\mathrm{Cr}$ content in poultry feed samples from Al-Qassim region, Saudi Arabia, ranged from 0.14 to $1.82 \mathrm{mg} / \mathrm{kg}$ (Alkhalaf et al. 2010). On the contrary, Tao et al. (2020) found higher Cr content (0.13-93.04 mg/ $\mathrm{kg}$ ) in poultry feed from Hubei province, China. The maximum acceptable limits for $\mathrm{Cr}$ concentrations in food range from 0.1 to $0.5 \mathrm{mg} / \mathrm{kg}$ for human (Alkhalaf et al. 2010). $\mathrm{Cr}$ toxicity increases reactive oxygen species damaging proteins and DNA. Its severity is dependent on the type of Cr; with $\mathrm{Cr}$ (VI) regarded as being carcinogenic and causing problems in the internal organs and the circulatory system (Dai et al. 2016).

Although $\mathrm{Cu}$ is a required element for various enzymatic activities and different body functions (NRC 1994), it is also known to be equally toxic and gains access to food constituents from environmental contamination, food processing or through the soil during mineralization by crops (Mahesar et al. 2010). In this study, the concentration of $\mathrm{Cu}$ ranged from 0.50 to $17.00 \mathrm{mg} / \mathrm{kg}$ and 3.0 to $24.70 \mathrm{mg} / \mathrm{kg}$ in feed samples from the north and central, respectively. The highest concentration of $\mathrm{Cu}(24.70 \mathrm{mg} / \mathrm{kg})$ was seen in layers mash feed from the central, while lowest levels were observed in maize samples from both regions. The range of $\mathrm{Cu}$ concentration found in this study was less than $19.2-36.1 \mathrm{mg} / \mathrm{kg}$ (Nicholson et al. 1999), 12.3-65.8 mg/kg (Mahesar et al. 2010) and 3.8-198.7 mg/kg (Wang et al. 2013) mentioned in the literature. The maximum permissible limit for copper in animal feed is $40 \mathrm{mg} / \mathrm{kg}$ (NRC 2005), and elevated concentrations of $\mathrm{Cu}$ in the human body provoke nausea, jaundice, diarrhoea, severe colic, liver and renal problems, as well as anaemia and Wilson's disease (Elsharawy and Elsharawy 2015; Ogwok et al. 2014).

Comparing the levels of heavy metal contamination between regions showed generally higher levels of toxic elements in the central and this occurrence could be probably due to the trace oil exploration activities that regularly pollutes the soils in the region. In addition, illegal artisanal heavy metal mining activities, use of leaded petrol and the dumping of electronic wastes have also been reported to contribute to environmental heavy metal contamination, poultry toxicity and human poisoning in Nigeria (Dooyema et al. 2012; Rabiu et al. 2019; Oladipo et al. 2020; Pona et al. 2021). Iftikhar et al. (2014) analysed the concentrations of heavy metals in milk samples from urban and rural areas in Pakistan and observed that samples from urban areas had higher levels of the toxic metals. Similarly, $\mathrm{Cu}$ levels in milk samples were higher in active mining areas with heavy 
metal-rich soils compared to other regions in Iran (Shahbazi et al. 2016).

\section{Conclusion}

The occurrence of AF and heavy metals in samples of maize, soybean meal, broiler finisher and layers mash was determined in two regions of Delta State, Nigeria. The result obtained from the study showed that AF contamination for all feed samples apart from maize in the northern region was marginally lower than permitted levels $(20 \mu \mathrm{g} / \mathrm{kg})$. On the other hand, AF contamination of samples from the central region was above-permitted levels, with soybean meal having the highest incidence of AF contamination. The data on heavy metals showed that while concentrations of $\mathrm{Cd}, \mathrm{Cr}$ and $\mathrm{Cu}$ were generally below permissible levels, the average concentration of $\mathrm{Pb}$ in broiler finisher and layers mash was above-permitted levels, which can induce toxic effects in poultry birds. In order to ascertain the route of $\mathrm{Pb}$ contamination in these feeds, it may be necessary to analyse feed component materials separately.

Taken together, there is the need for constant monitoring of $\mathrm{AF}$ and $\mathrm{Pb}$ levels in poultry feeds and ingredients in these regions to ensure strict compliance with international standards and regulations. Furthermore, employing practical and cost-effective intervention measures for controlling $\mathrm{AF}$ and $\mathrm{Pb}$ contamination in developing countries will help reduce the health and economic risks associated with their occurrence.

Author contributions I.I designed the experiments and wrote the first draft of the manuscript. C. I., P. I. and W.A conducted the experiments under the supervision of I. I. O. O analyzed the data for the manuscript. I. I., U. A. E and J. O. A contributed to writing and preparation of the final manuscript. All authors read and approved the final manuscript.

\section{Declarations}

Conflict of interest The authors have no conflicts of interest to declare that are relevant to the content of this article.

Open Access This article is licensed under a Creative Commons Attribution 4.0 International License, which permits use, sharing, adaptation, distribution and reproduction in any medium or format, as long as you give appropriate credit to the original author(s) and the source, provide a link to the Creative Commons licence, and indicate if changes were made. The images or other third party material in this article are included in the article's Creative Commons licence, unless indicated otherwise in a credit line to the material. If material is not included in the article's Creative Commons licence and your intended use is not permitted by statutory regulation or exceeds the permitted use, you will need to obtain permission directly from the copyright holder. To view a copy of this licence, visit http://creativecommons.org/licenses/by/4.0/.

\section{References}

Aboagye-Nuamah F, Kwoseh CK, Maier DE (2021) Toxigenic mycoflora, aflatoxin and fumonisin contamination of poultry feeds in Ghana. Toxicon 198:164-170. https://doi.org/10.1016/j.toxicon. 2021.05.006

Adegbeye MJ, Reddy PRK, Chilaka CA, Balogun OB, Elghandour MM, Rivas-Caceres RR, Salem AZ (2020) Mycotoxin toxicity and residue in animal products: Prevalence, consumer exposure and reduction strategies-A review. Toxicon 177:96-108. https:// doi.org/10.1016/j.toxicon.2020.01.007

Ahmed S, Fatema-Tuj-Zohra KMSH, Hashem MA (2017) Chromium from tannery waste in poultry feed: a potential cradle to transport human food chain. Cogent Environ Sci 3(1):1312767. https://doi. org/10.1080/23311843.2017.1312767

Akhtar S, Shahzad MA, Yoo S-H, Ismail A, Hameed A, Ismail T, Riaz M (2017) Determination of aflatoxin M1 and heavy metals in infant formula milk brands available in Pakistani markets. Korean J Food Sci Anim Resour 37(1):79

Akinmusire OO, El-Yuguda A-D, Musa JA, Oyedele OA, Sulyok M, Somorin YM, Ezekiel CN, Krska R (2019) Mycotoxins in poultry feed and feed ingredients in Nigeria. Mycotoxin Res 35(2):149155. https://doi.org/10.1007/s12550-018-0337-y

Alexieva D, Chobanova S, Ilchev A (2007) Study on the level of heavy metal contamination in feed materials and compound feed for pigs and poultry in Bulgaria. Trakia J Sci 5(2):61-66

Alkhalaf NA, Osman AK, Salama KA (2010) Monitoring of aflatoxins and heavy metals in some poultry feeds. Afr J Food Sci 4(4):192-199

Alloway BJ (2013) Sources of heavy metals and metalloids in soils. Heavy metals in soils. Springer, Dordrecht, pp 11-50

AOAC (1990) Official Methods of Analysis of AOAC International, 5 th revision; AOAC

Bhat Ramesh V, Vasanthi S (2003) Mycotoxin food safety risk in developing countries. In.: International Food Policy Research Institute (IFPRI); 2003

Blair BF, Lamb MC (2017) Evaluating concentrations of pesticides and heavy metals in the US peanut crop in the presence of detection limits. Peanut Sci 44(2):124-133. https://doi.org/10.3146/ PS17-6.1

Cang L, Wang Y-j, Zhou D-m, Dong Y-h (2004) Heavy metals pollution in poultry and livestock feeds and manures under intensive farming in Jiangsu Province. China J Environ Sci 16(3):371-374

Commission E (2006) Commission Recommendation of 17 August 2006 on the presence of deoxynivalenol, zearalenone, ochratoxin A, T-2 and HT-2 and fumonisins in products intended for animal feeding (2006/576/EC). J Eur Union 229:7-9

Dai SY, Jones B, Lee K-M, Li W, Post L, Herrman TJ (2016) Heavy metal contamination of animal feed in Texas. J Regul Sci $4(1): 21-32$

Daodu O, Adebowale T (2016) Aflatoxin in commercial poultry feeds and clinico-pathological manifestation of aflaxoxicosis in poultry in Southwest. Nigeria Niger Vet J 37(2):109-116

Diedhiou PM, Bandyopadhyay R, Atehnkeng J, Ojiambo PS (2011) Aspergillus colonization and aflatoxin contamination of maize and sesame kernels in two agro-ecological zones in Senegal. J Phytopathol 159(4):268-275. https://doi.org/10.1111/j.14390434.2010.01761.x

D’Mello JF (1997) Handbook of plant and fungal toxicants. CRC Press, Boca Raton

Dooyema CA, Neri A, Lo YC, Durant J, Dargan PI, Swarthout T, Biya O, Gidado SO, Haladu S, Sani-Gwarzo N, Nguku PM (2012) Outbreak of fatal childhood lead poisoning related to artisanal gold mining in northwestern Nigeria, 2010 Environ. Health Perspect 120(4):601-607. https://doi.org/10.1289/ehp.1103965 
Duruibe JO, Ogwuegbu M, Egwurugwu J (2007) Heavy metal pollution and human biotoxic effects. Int J Phys Sci 2(5):112-118

Elliott S, Frio A, Jarman T (2017) Heavy metal contamination of animal feedstuffs-a new survey. J Appl Anim Nutr, 5

Elsharawy NTM, Elsharawy M (2015): Some heavy metals residues in chicken meat and their edible offal in New Valley. In: 2nd conference of food safety: 2015: Suez Canal University, Faculty of Veterinary Medicine; $50-57$

Eskandari M, Pakfetrat S (2014) Aflatoxins and heavy metals in animal feed in Iran. Food Addit Contam Part B 7(3):202-207. https://doi. org/10.1080/19393210.2013.876675

EU (2013) Commission regulation (EU) No 1275/2013 of 6 december 2013 amending annex I to directive 2002/32/EC of the European parliament and of the council as regards maximum levels for arsenic, cadmium, lead, nitrites, volatile mustard oil and harmful botanical impurities. Off J Eur Union 328:86-92

European Food Safety Authority (EFSA) (2004) Opinion of the scientific panel on contaminants in the food chain on a request from the commission related to cadmium as undesirable substance in animal feed. EFSA J 72:1-24

European Food Safety Authority (EFSA) (2009) Scientific opinion of the panel on contaminants in the food chain: cadmium in food. EFSA J 980:1-139

Ezekiel C, Bandyopadhyay R, Sulyok M, Warth B, Krska R (2012) Fungal and bacterial metabolites in commercial poultry feed from Nigeria. Food Addit Contam Part A 29(8):1288-1299. https://doi.org/10.1080/19440049.2012.688878

Ezekiel CN, Warth B, Ogara IM, Abia WA, Ezekiel VC, Atehnkeng J, Sulyok M, Turner PC, Tayo GO, Krska R (2014) Mycotoxin exposure in rural residents in northern Nigeria: a pilot study using multi-urinary biomarkers. Environ Int 66:138-145. https://doi.org/10.1016/j.envint.2014.02.003

FAO (2004) Worldwide Regulations for Mycotoxins in Food and Feed in 2003. Food and Nutrition Paper No. 81. Food Agriculture Organization of the United Nations, Rome, Italy

Fink-Gremmels J (2012) Animal feed contamination: Effects on livestock and food safety

Getachew A, Chala A, Hofgaard IS, Brurberg MB, Sulyok M, Tronsmo A-M (2018) Multimycotoxin and fungal analysis of maize grains from south and southwestern Ethiopia. Food Addit Contam Part B 11(1):64-74. https://doi.org/10.1080/19393210. 2017.1408698

Gruber-Dorninger C, Jenkins T, Schatzmayr G (2018) Multi-mycotoxin screening of feed and feed raw materials from Africa. World Mycotoxin Journal 11(3):369-383. https://doi.org/10.3920/ WMJ2017.2292

Hinton M (2000) Infections and intoxications associated with animal feed and forage which may present a hazard to human health. Vet J 159(2):124-138. https://doi.org/10.1053/tvjl.1999.0412

Ifie I, Olatunde S, Ogbon O, Umukoro JE (2021) Processing techniques on phytochemical content, proximate composition, and toxic components in duckweed. Int J of Veg Sci 27(3):294-302. https://doi. org/10.1080/19315260.2020.1781320

Iftikhar B, Arif S, Siddiqui S, Khattak R (2014) Assessment of toxic metals in dairy milk and animal feed in Peshawar. Pakistan Biotechnol J Int. https://doi.org/10.9734/BBJ/2014/9939

Imade F, Ankwasa EM, Geng H, Ullah S, Ahmad T, Wang G, Zhang C, Dada O, Xing F, Zheng Y (2021) Updates on food and feed mycotoxin contamination and safety in Africa with special reference to Nigeria. Mycology. 12:1-16

Imran R, Hamid A, Amjad R, Chaudhry C, Yaqub G, Akhtar S (2014) Evaluation of heavy metal concentration in the poultry feeds. $\mathbf{J}$ Bio Env Sci 5:394-404

Ismail A, Riaz M, Akhtar S, Ismail T, Amir M, Zafar-ul-Hye M (2014) Heavy metals in vegetables and respective soils irrigated by canal, municipal waste and tube well waters. Food Addit Contam Part B 7(3):213-219. https://doi.org/10.1080/19393210.2014.888783

Järup L (2003) Hazards of heavy metal contamination. Br Med Bull 68(1):167-182

Javed I, Jan I, Muhammad F, Khan MZ, Aslam B, Sultan JI (2009) Heavy metal residues in the milk of cattle and goats during winter season. Bull Environ Contam Toxicol 82(5):616-620

Joint, F. A. O., World Health Organization, \& WHO Expert Committee on Food Additives (2017) Evaluation of certain contaminants in food: eighty-third report of the Joint FAO/WHO Expert Committee on Food Additives. World Health Organization

Kaaya AN, Kyamuhangire W (2006) The effect of storage time and agroecological zone on mould incidence and aflatoxin contamination of maize from traders in Uganda. Int J Food Microbiol 110(3):217-223. https://doi.org/10.1016/j.ijfoodmicro.2006.04. 004

Kana JR, Gnonlonfin BGJ, Harvey J, Wainaina J, Wanjuki I, Skilton RA, Teguia A (2013) Assessment of aflatoxin contamination of maize, peanut meal and poultry feed mixtures from different agroecological zones in Cameroon. Toxins 5(5):884-894. https://doi. org/10.3390/toxins5050884

Karak T, Bhagat R (2010) Trace elements in tea leaves, made tea and tea infusion: a review. Food Res Int 43(9):2234-2252. https://doi. org/10.1016/j.foodres.2010.08.010

Kemboi DC, Ochieng PE, Antonissen G, Croubels S, Scippo M-L, Okoth S, Kangethe EK, Faas J, Doupovec B, Lindahl JF (2020) Multi-mycotoxin occurrence in dairy cattle and poultry feeds and feed ingredients from Machakos town. Kenya Toxins 12(12):762. https://doi.org/10.3390/toxins12120762

Lanyasunya T, Wamae L, Musa H, Olowofeso O, Lokwaleput I (2005) The risk of mycotoxins contamination of dairy feed and milk on smallholder dairy farms in Kenya. Pak J Nutr 4(3):162-169

Li G, Liu C, Zhang X, Luo P, Lin G, Jiang W (2021) Highly photoluminescent carbon dots-based immunosensors for ultrasensitive detection of aflatoxin M1 residues in milk. Food Chem 355:129443. https://doi.org/10.1016/j.foodchem.2021.129443

Magan N, Lacey J (1988) Ecological determinants of mould growth in stored grain. Int J Food Microbiol 7(3):245-256. https://doi.org/ 10.1016/0168-1605(88)90043-8

Magnoli AP, Poloni VL, Cavaglieri L (2019) Impact of mycotoxin contamination in the animal feed industry. Curr Opin Food Sci 29:99-108. https://doi.org/10.1016/j.cofs.2019.08.009

Mahesar S, Sherazi S, Niaz A, Bhanger M, Rauf A (2010) Simultaneous assessment of zinc, cadmium, lead and copper in poultry feeds by differential pulse anodic stripping voltammetry. Food Chem Toxicol 48(8-9):2357-2360. https://doi.org/10.1016/j.fct. 2010.05.071

Mannaa M, Kim KD (2017) Influence of temperature and water activity on deleterious fungi and mycotoxin production during grain storage. Mycobiology 45(4):240-254. https://doi.org/10.5941/ MYCO.2017.45.4.240

Morrison DM, Ledoux DR, Chester LF, Samuels CA (2017) A limited survey of aflatoxins in poultry feed and feed ingredients in Guyana. Vet Sci 4(4):60. https://doi.org/10.3390/vetsci4040060

Mutegi C, Wagacha M, Kimani J, Otieno G, Wanyama R, Hell K, Christie ME (2013) Incidence of aflatoxin in peanuts (Arachis hypogaea Linnaeus) from markets in Western, Nyanza and Nairobi Provinces of Kenya and related market traits. J Stored Prod Res 52:118-127. https://doi.org/10.1016/j.jspr.2012.10.002

Nakavuma JL, Kirabo A, Bogere P, Nabulime MM, Kaaya AN, Gnonlonfin B (2020) Awareness of mycotoxins and occurrence of aflatoxins in poultry feeds and feed ingredients in selected regions of Uganda. Int J Food Contam 7(1):1-10. https://doi.org/10.1186/ s40550-020-00079-2

Nasaruddin N, Jinap S, Samsudin NI, Kamarulzaman NH, Sanny M (2021) Prevalence of mycotoxigenic fungi and assessment of 
aflatoxin contamination: a multiple case study along the integrated corn-based poultry feed supply chain in Malaysia. J Sci Food Agric 101(5):1812-1821. https://doi.org/10.1002/jsfa.10795

Nasir U, Naeem I, Asif M, Ismail A, Gong YY, Routledge MN, Amjad A, Fazal A, Ismail Z (2021) Assessment of aflatoxins exposure through urinary biomarker approach and the evaluation of the impacts of aflatoxins exposure on the selected health parameters of the children of Multan city of Pakistan. Food Control 123:107863. https://doi.org/10.1016/j.foodcont.2021.107863

National Research Council NRC (1994) Nutrient requirements of poultry, toxicity of certain inorganic elements, 9th edn. National Academy Press, Washington, DC, USA, pp 58-60

Nemati M, Mehran MA, Hamed PK, Masoud A (2010) A survey on the occurrence of aflatoxin M1 in milk samples in Ardabil. Iran Food Control 21(7):1022-1024. https://doi.org/10.1016/j.foodc ont.2009.12.021

Nicholson FA, Chambers BJ, Williams J, Unwin R (1999) Heavy metal contents of livestock feeds and animal manures in England and Wales. Bioresour Technol 70(1):23-31. https://doi.org/10.1016/ S0960-8524(99)00017-6

NRC (2005) Mineral tolerances of animals. National Academies Press, Washington, DC

Ogwok P, Bamuwamye M, Apili G, Musalima JH (2014) Health risk posed by lead, copper and iron via consumption of organ meats in Kampala City (Uganda). J Environ Pollut Hum Health 2(3):69-73

Oladipo OO, Akanbi OB, Ekong PS, Uchendu C, Ajani O (2020) Lead toxicoses in free-range chickens in artisanal gold-mining communities, Zamfara. Nigeria J Health Pollut 10(26):200606. https:// doi.org/10.5696/2156-9614-10.26.200606

Oliveira MS, Rocha A, Sulyok M, Krska R, Mallmann CA (2017) Natural mycotoxin contamination of maize (Zea mays L.) in the South region of Brazil. Food Control 73:127-132. https://doi.org/ 10.1016/j.foodcont.2016.07.033

Organization WH, Cancer IAfRo (1993) Some naturally occurring substances: food items and constituents, heterocyclic aromatic amines and mycotoxins. IARC Monographs on the Evaluation of the Carcinogenic Risk of Chemicals to Humans. 56

Peralta-Videa JR, Lopez ML, Narayan M, Saupe G, Gardea-Torresdey J (2009) The biochemistry of environmental heavy metal uptake by plants: implications for the food chain. Int J Biochem Cell Biol 41(8-9):1665-1677. https://doi.org/10.1016/j.biocel.2009.03.005

Perrone G, Haidukowski M, Stea G, Epifani F, Bandyopadhyay R, Leslie JF, Logrieco A (2014) Population structure and Aflatoxin production by Aspergillus Sect. Flavi from maize in Nigeria and Ghana. Food Microbiol 41:52-59. https://doi.org/10.1016/j.fm. 2013.12.005

Pona HT, Xiaoli D, Ayantobo OO, Tetteh ND (2021) Environmental health situation in Nigeria: current status and future needs. Heliyon 7(3):e06330. https://doi.org/10.1016/j.heliyon.2021.e06330

Rabiu S, Abubakar MG, Sahabi DM, Makusidi MA, Dandare A (2019) Co-Exposure to Lead and Mercury among Artisanal Gold Miners. Asian J Environ Sci, 1-8 https://doi.org/10.9734/ajee/2019/ v11i330140

Rebelo FM, Caldas ED (2016) Arsenic, lead, mercury and cadmium: toxicity, levels in breast milk and the risks for breastfed infants. Environ Res 151:671-688. https://doi.org/10.1016/j.envres.2016. 08.027
Rodrigues I, Handl J, Binder E (2011) Mycotoxin occurrence in commodities, feeds and feed ingredients sourced in the Middle East and Africa. Food Addit Contam Part B 4(3):168-179. https://doi. org/10.1080/19393210.2011.589034

Shahbazi Y, Ahmadi F, Fakhari F (2016) Voltammetric determination of $\mathrm{Pb}, \mathrm{Cd}, \mathrm{Zn}, \mathrm{Cu}$ and $\mathrm{Se}$ in milk and dairy products collected from Iran: an emphasis on permissible limits and risk assessment of exposure to heavy metals. Food Chem 192:1060-1067. https:// doi.org/10.1016/j.foodchem.2015.07.123

Sharma M, Maheshwari M, Morisawa S (2005) Dietary and inhalation intake of lead and estimation of blood lead levels in adults and children in Kanpur. India Risk Anal Int J 25(6):1573-1588. https://doi.org/10.1111/j.1539-6924.2005.00683.x

Shephard GS (2008) Risk assessment of aflatoxins in food in Africa. Food Addit Contam 25(10):1246-1256. https://doi.org/10.1080/ 02652030802036222

Tajkarimi M, Faghih MA, Poursoltani H, Nejad AS, Motallebi A, Mahdavi H (2008) Lead residue levels in raw milk from different regions of Iran. Food Control 19(5):495-498. https://doi.org/10. 1016/j.foodcont.2007.05.015

Tao C, Wei X, Zhang B, Zhao M, Wang S, Sun Z, Qi D, Sun L, Rajput SA, Zhang N (2020) Heavy metal content in feedstuffs and feeds in Hubei Province. China J Food Prot 83(5):762-766. https://doi. org/10.4315/0362-028X.JFP-18-539

Thanushree MP, Sailendri D, Yoha KS, Moses JA, Anandharamakrishnan C (2019) Mycotoxin contamination in food: an exposition on spices. Trends Food Sci Technol 93:69-80. https://doi.org/ 10.1016/j.tifs.2019.08.010

Thirumala-Devi K, Mayo M, Reddy G, Reddy D (2002) Occurrence of aflatoxins and ochratoxin A in Indian poultry feeds. J Food Prot 65(8):1338-1340. https://doi.org/10.4315/0362-028X-65.8.1338

USDA Foreign Agricultural Service (USDA-FAS). GAIN report: Nigeria grain and feed annual 2010. Washington (DC) Department of Agriculture

Xu F, Baker RC, Whitaker TB, Luo H, Zhao Y, Stevenson A, Boesch CJ, Zhang G (2021) Review of good agricultural practices for smallholder maize farmers to minimise aflatoxin contamination. World Mycotoxin J. https://doi.org/10.3920/WMJ2021.2685

Vidovic M, Sadibasic A, Cupic S, Lausevic M (2005) Cd and Zn in atmospheric deposit, soil, wheat, and milk. Environ Res 97(1):2631. https://doi.org/10.1016/j.envres.2004.05.00

Vincent JB (2017) New evidence against chromium as an essential trace element. J Nutr 147(12):2212-2219. https://doi.org/10.3945/ jn. 117.255901

Wang H, Dong Y, Yang Y, Toor GS, Zhang X (2013) Changes in heavy metal contents in animal feeds and manures in an intensive animal production region of China. J Environ Sci 25(12):2435-2442. https://doi.org/10.1016/S1001-0742(13)60473-8

Wolf P, Cappai MG (2020) Levels of Pb and Cd in single feeding stuffs and compound feeds for poultry. Biol Trace Elem Res. https://doi. org/10.1007/s12011-020-02197-6

Yurdakök K (2015) Lead, mercury, and cadmium in breast milk. J Pediatric Neonatal Individ Med (JPNIM) 4(2):e040223-e040223

Zinedine A, Juan C, Soriano J, Molto J, Idrissi L, Manes J (2007) Limited survey for the occurrence of aflatoxins in cereals and poultry feeds from Rabat. Morocco Int J Food Microbiol 115(1):124-127. https://doi.org/10.1016/j.ijfoodmicro.2006.10.013 